\title{
NOTES
}

\section{"A MODERN POET ON THE SCOTCH BARD": WALT WHITMAN'S 1875 ESSAY ON ROBERT BURNS}

In his 1996 essay "Whitman on Robert Burns: An Early Essay Recovered," Gary Scharnhorst draws attention to an early critical essay on Burns that had "hitherto been lost to scholarship." The essay to which he refers, titled "A Modern Poet on The Scotch Bard," first appeared in an ephemeral newspaper titled Our Land and Time in January 1875 and was subsequently reprinted in the London Academy in February that same year. Whitman later revised the essay for publication-changing the title to "Robert Burns as Poet and Person"-in the New York Critic (1882), and made minor textual edits for the North American Review in 1886. The North American Review version also appeared three times in 1888-in November Boughs, Democratic Vistas and Other Papers (London: Walter Scott), and Complete Poems and Prose.

Critics of Burns have frequently referenced "Robert Burns as Poet and Person" when commenting on the possible influence of Burns on Whitman and, more broadly, American literature. Though Scharnhorst drew attention to the discovery of the 1875 early version almost two decades ago, remarkably little has since been written about the essay by scholars of Burns or Whitman. Revisiting Whitman's "lost" essay is a useful exercise in helping to accentuate and enhance our understanding of his views on Burns. The complete lack of critical engagement with "A Modern Poet on The Scotch Bard" means that, hitherto, we do not have the fullest possible sense of the American poet's appraisal. I will begin by considering some of the existing commentary regarding "Robert Burns as Poet and Person" before going on to examine the "lost" passages of the 1875 essay.

Quite often, the more laudatory aspects of "Robert Burns as Poet and Person" have been strongly emphasized in Burns scholarship, leading to the popular assumption that the American poet "admired and praised Burns" and identified with the "inextricable linkage of American liberty and the common man in Burns's art and thought." 2 Perhaps the most commonly quoted, and thus influential, passage from the 1882 and 1886 essays has been Whitman's powerful proclamation that:

... there are many things in Burns's poems and character that specially endear him to America. He was essentially a Republican-would have been at home in the Western United States, and probably become eminent there. He was an average sample of the good-natured, warm-blooded, proud-spirited, amative, alimentive, convivial, young and early-middle-aged man of the decent-born middle classes everywhere and any how. Without the race of which he is a distinct specimen, (and perhaps his poems) America and her powerful Democracy could not exist to-day-could not project with unparallel'd historic sway in the future. ${ }^{3}$ 
The esteem of Whitman, as well as praise by Ralph Waldo Emerson, ${ }^{4}$ certainly contributed to Burns becoming "an idol of both cultural and literary proportions for the nineteenth-century American reading public." ${ }^{5}$ However, as Carol McGuirk and Robert Crawford have noted, a fuller reading of Whitman's 1886 essay reveals that the American poet was not entirely complimentary about Burns, despite heralding him as the "tenderest, manliest, and (even if contradictory) dearest flesh-and-blood figure in all the streams and clusters of by-gone poets" (NB 64; PW 2:568). In an excellent essay, McGuirk suggests that Whitman seems both "amazed and rather put off" by Burns's "emphatic rhyming sound," asserting that the strong influence of Wordsworth may have rendered Burns's verse "too informal for direct and full imitation by nineteenth-century American poets or too direct." ${ }^{\prime}$ Indeed, in Whitman's revised 1886 essay, he describes Burns's versification as "idiomatic ear-cuffing" restricted by a "low and contracted" understanding of poetry $(N B$ 63; $P W$ 2:567-568). While praising the "raciness" and "humour" of Burns's "genuine poetic imagination," Whitman derides the morality in Burns's poetry, rendering it "hardly more than parrot talk" (NB 60-61; PW 2:563). While Whitman may have loved "the personality of the man, or at least his fantasy of the man,"” it seems he was not entirely enthusiastic about his poetry. Referring to what was widely considered to be-prior to Scharnhorst's 1996 article - the "earliest" version of Whitman's essay, McGuirk describes how the American poet was eager to express his distaste for Burns's "Scottish nationalism":

In an outburst included in the earliest published version of his essay (The Critic 1882) but deleted in later printings, Whitman explicitly dissociates himself from the Scottish nationalism which he perceives as marking Burns's cult as well as Burns's poems.... Whitman cannot praise Burns's Scotland-centred bardic consciousness because he sees it as tied to a decadent political system and to superseded values. (148)

Though Whitman, like Burns, was deeply concerned with nationalism, he viewed the role of the bard as a forward-thinking far-seer rather than a provincial poet. Whitman seems to miss Burns's conflation of the provincial with the universal, and suggests that the Scottish poet's declared aim to be a "Rustic Bard" is far from progressive and lacks comprehensive literary merit: "His collected works, in giving everything, are nearly one half first drafts. His brightest hit is his use of the Scotch patois" (PW 2:566).

There is also the matter of Whitman's decision to change the title of the essay. The earlier "A Modern Poet on The Scotch Bard" immediately divorces Whitman from Burns-Whitman here positions himself as the beacon of modernity and progression, and sets himself apart from the patriotic "Scotch Bard" concerned with an ancestral past. The later title, "Robert Burns as Poet and Person," does not advocate Whitman's "modern" superiority. These two notable edits suggest that Whitman was, over time, increasingly anxious not to seem brash about a poet he endearingly referred to as "Dear Rob" (PW 2:566). Robert Crawford has described Whitman's repeated revisions on Burns as an attempt to "come to terms with a persistent anxiety of influence." ${ }^{\text {B }}$ Crawford's essay, published in 2012, does acknowledge the $1875 \mathrm{draft}$ (in footnote form), 
making the valuable observation that Whitman seems to moderate his criticisms each time. That is, with each edit, Whitman appears to dilute the more negative passages in regards to Burns's poetic craft. In the final paragraph of the 1886 essay, Whitman concedes to "drawing black marks" but further comments: "in the present outpouring I have 'kept myself in,' rather than allow'd any free flow" (PW 2:568). This further suggests that Whitman may have contained some of his more critical opinions due to his unabashed fondness for the character-or at least the fantasy — of Robert Burns "as person."

In terms of Whitman scholarship, the most recent and comprehensive study of the relationship between the two poets is featured in Gary Schmidgall's 2014 book Containing Multitudes: Walt Whitman and The British Literary Tradition. In his chapter "Burns and Whitman," Schmidgall not only assesses the possible influence of Burns on Whitman, but also provides a useful comparison between the poets by highlighting what draws them together and sets them apart respectively. While noting the "highly evocative intersections" that "draw Burns and Whitman together" (namely their "bardic" ambitions and penchant for writing "heart-driven" poetry), Schmidgall also asserts how their approach to writing poetry was radically different. ${ }^{9}$ Most interestingly, he suggests that Whitman "distance[s] himself from Burns" through his choice not to employ an idiosyncratic dialect:

Calling the Scots dialect Burns's "happiest hit" leaves the impression that Whitman saw it as something of a gimmick.... In any case, Whitman could confidently distance himself from Burns in the use of dialect, since he himself was never tempted to indulge in rural dialect or the "nigger" or "black face" patois that was popular in nineteenthcentury America. (118-119)

While Schmidgall's commentary on the two poets is extensive, nuanced, and often highly insightful, he too appears to miss the significance of Whitman's 1875 "A Modern Poet on The Scotch Bard." In a section of the chapter subtitled "Walt Reads Rob," Schmidgall addresses "Robert Burns as Poet and Person" from the 1882 New York Critic, before discussing the 1887 revision that was written "as the poet's $128^{\text {th }}$ anniversary neared" (119). Schmidgall does-in recognizing the need to read "between the lines" of Whitman's rather ambiguous essay - point to the existence of "a half-dozen manuscripts containing notes on Burns and several unguarded observations about him in conversation with Traubel," with the latter being particularly useful in clarifying "Whitman's contradictory response to Burns" (122). Though Schmidgall's reference to the "half dozen manuscripts" might well have included the 1875 draft, it is rather unlikely given it is not mentioned in the entirety of the chapter, whereas Whitman's minor references to Burns in various poetic manuscripts continue to be cited.

Let us turn our attention, then, to the repeatedly ignored 1875 essay in order to extrapolate some of the passages that were omitted from the two later drafts. This essay was published in Our Land and Time on January 25, 1875, the $116^{\text {th }}$ anniversary of the birth of Robert Burns. The occasion did not go unnoticed by Whitman, who begins by expressing his distaste for celebratory "Burns Suppers": 
To-day, and especially to-night at the suppers and drinks and speeches, how much will be said, to be afterwards gradually filtered through East and West, North and South, about Robert Burns particularly and about poetry and poets in general.... First premising to thee, reader dear, that the undersigned has been courteously summoned by letter and ticket to more than one of to-night's supper anniversaries, the way may then be clearer and the reason why for thoughts like the following, not of extravagant eulogium, with voice pitched high and fervent to the pleasant smell of hot Scotch, but alone by the fireside in the invalid room, weighing the canny Caledonian bard in friendly scale, yet seeking to strike the eternal averages. (Scharnhorst 217)

Whitman conjures a striking image of himself "alone by the fireside" contemplating Burns's life and work in measured, composed fashion. The American poet's refusal to attend "suppers and drinks" signifies his rejection of "extravagant eulogium" in favor of engaging with Burns's poetry. Ironically, of course, critics would later eulogize Whitman's "praise" for Burns, yet this opening paragraph reveals his desire to refrain from hyperbole and extravagant remarks. Fifty years prior to Hugh MacDiarmid's famous derision of the "Burns cult" in A Drunk Man Looks at The Thistle, ${ }^{10}$ it seems Whitman also took issue with the laudatory annual occasions where poetry was recited with "voice pitched high" to the "smell of hot Scotch." In its blatant rejection of "supper anniversaries" and "extravagant eulogium," the 1875 essay explicitly, and to a far greater extent than subsequent drafts, conveys Whitman's distaste for commemorative Burns "suppers" and "events." Interestingly, this sets the poet apart from many of his nineteenth-century contemporaries, in that Emerson, Lowell, and Holmes, among others, chose to partake in at least one "supper" in which they offered high, elegiac praise for Burns. ${ }^{11}$ Whitman's strong rejection of "eulogium" suggests a much rarer nineteenth-century attitude that emphasizes engagement with Burns's poetry rather than the memory of the poet himself.

Whitman subsequently turns his attention to the timely need for Americans to study poetry. Once again, he is more expansive than in the later versions of the essay about his conflation of poetry and politics:

The study of poetry and the poets-needed for these States and to our 1875 and '76 the same as ever, and for modern democracy just as much as past-time feudalism and ecclesiasticism - remains a vivid and profound study, only demanding some new interpellations.... And I may say here what for some time I have not hid from my friends - an opinion that the distinctive Democracy and new life which America stands for, are yet to receive their best proof and crowning charm from native outgrowths of verse, and imaginative literature adjusted to them, reaching far deeper and higher even than our politics, election-days, and our free and universal ballot. (Scharnhorst 218)

Here, Whitman emphasizes the need for an American Literature that reaches "higher even than our politics," but goes on to suggest that Burns's verse is no model for such a task. Labelling his poems as "humdrum samples" of Democracy, Whitman further claims that Republicanism has not been well served by poets: 
(To be plain, the new dispensation of Republicanism is not over-well served by its bards, so called, anywhere; the singers of feudalism and ecclesiasticism, after all have served it better.) (Scharnhorst 218)

Whitman's literary and political assertions are here at their most raw. His calls for an "imaginative literature" for the "new life which America stands for" are omitted from later versions of the essay. Moreover, the idea that Whitman admired Burns for his linkage to "American liberty" or politics is thrown into question through his assertion that the poet "attempts none of these themes" (218). From the 1875 version alone, Burns is certainly not to be considered a great democratic or political poet.

Whitman is also more expansive in his references to Burns's supposed "character" in the 1875 essay:

Though there is always this point, and of the very highest, to be made in favour of Burns. The recognition of generous and powerful typical character, either in its standards in the world of things or moral and aesthetic standards, pervades him throughout. To completely formulate that ideal perfection for the acceptance of the United States is yet unknown in literature. To realize it, seek it, act upon it, is a help not to be dispised [sic]. A poet or artist in whose productions this fervid recognition is discovered, and by whom its realization is personally striven for (perhaps amid many escapades and errors), will often be dearer to the race than others even of more correct life and superior technical art. (Byron, George Sand, Schiller, and Burns illustrate this). (Scharnhorst 218-219)

There is also a sense that Whitman may be using Burns to his own ends. That is, he sets himself up as democratic national poet by pointing out that hitherto there has been an absence of one. His allusion to a "more correct life" (219) also touches on a consistent current in the later versions of his critical appraisal, in which Burns is described as having never "extricated himself" from "his own rank appetites" ( $P W 2: 564)$. While Whitman's commentary is more nuanced and thoughtful than many of his contemporaries, it seems he was not completely unaffected by the easy moralizing of James Currie's 1800 edition. In a telling passage towards the end of the 1875 essay (subsequently omitted), Whitman passes final judgement on Burns as a poet:

Though so really equal and independent, he prided himself in his songs on being a cavalier and a Jacobite. We shall have to call him a poet of the third, perhaps fourth class. (Scharnhorst 219)

Here, Whitman makes clear that Burns is too backwards looking in his bardicconsciousness. Despite being "equal and independent," Burns, for Whitman, is too concerned with history to be a truly forward-looking, democratic bard. This adheres to McGuirk's assertion that Whitman fails to see Burns's vision of Scotland as a future "reborn sovereign Scotland," and instead mistakes his poetry for mere "ancestor worship" (149). 
A fuller reading of the 1875 essay, then, not only reinforces some of the points Whitman makes about Burns in later drafts but provides new insights that deepen our understanding of his views on the Scottish poet. When Whitman stated at the end of his 1886 essay that "I have kept myself in," he may well have been referring to some of the omitted passages from his original "A Modern Poet on The Scotch Bard.” The 1875 essay is blatant in its criticism of the nineteenth-century culture of commemoration, a significant observation in that many of Whitman's literary contemporaries regularly composed works for such occasions, "suppers," and events as previously outlined. Moreover, Whitman is far more visceral in his criticisms of Burns's poetry in the earliest draft ("a poet of the third, perhaps fourth class"), moderating his analysis with each edit, resulting in a final essay that, perhaps, represents a glossed version of his truer sentiments. ${ }^{12}$ One certainty is that in reading all three drafts of Whitman's essay on Burns, it becomes apparent that his opinions extend far beyond mere blind adoration. For this reason, it is important to carefully consider all three drafts - paying close attention to textual differences-before making any grand claims about Burns being influential on Whitman.

\section{University of Glasgow}

ARUn SoOd

\section{NOTES}

1 Gary Scharnhorst, "Whitman on Robert Burns: An Early Essay Recovered," Walt Whitman Quarterly Review 13 (Spring 1996), 217.

2 Roger J. Fechner, "Burns and American Liberty," in Kenneth Simpson, ed., Love and Liberty: Robert Burns, A Bicentenary Celebration (East Linton: Tuckwell, 1997), 285.

3 Walt Whitman, November Boughs (Philadelphia: David McKay, 1888), 57, hereafter, NB; and Whitman, Prose Works 1892, ed. Floyd Stovall (New York: New York University Press, 1964), 2:559, hereafter, $P W$.

4 See Ralph Waldo Emerson, "Speech at Burns Centenary Dinner in Boston, January 1859," in Donald A. Low, ed., Robert Burns: The Critical Heritage (London: Routledge, 1974), 434-436.

5 Rhona Brown, “'Guid black prent': Robert Burns and the Contemporary Scottish and American Periodical Press," in Sharon Alker, Leith Davis, and Holly Faith Nelson, eds., Robert Burns and Transatlantic Culture (Farnham, Surrey, UK: Ashgate, 2012), 71, hereafter, RBTC.

6 Carol McGuirk, "Haunted By Authority: Nineteenth-Century American Constructions of Robert Burns and Scotland," in Robert Crawford, ed., Robert Burns and Cultural Authority (Iowa City: University of Iowa Press, 1997), 142.

7 Ibid., 149.

8 Robert Crawford, “America's Bard,” in RBTC, 110.

9 Gary Schmidgall, Containing Multitudes: Walt Whitman and The British Literary Tradition (New York: Oxford University Press, 2014), 124, 117.

10 Hugh MacDiarmid, A Drunk Man Looks at the Thistle (Edinburgh: Blackwood, 1926). 
11 See for example, Celebration of the Hundredth Anniversary of the Birth of Robert Burns, by the Boston Burns Club. Fanuary 25th, 1859 (Boston: H.W. Dutton and Son, 1859).

12 In 1888, two years after the final version of his essay was published, Whitman told Horace Traubel: "On one point I am not as well understood as I would wish to be: as to the old feeling of pride in the rustic because he was rustic-Burns, Millet, Whittier: I do not share that pride myself: whatever it may be it is not modern-is not equi-large with the newer meanings of civilization." See Horace Traubel, With Walt Whitman in Camden, vol. 3 (New York: Mitchell Kennerley, 1912), 89-90. Available on the Walt Whitman Archive (whitmanarchive.org). 